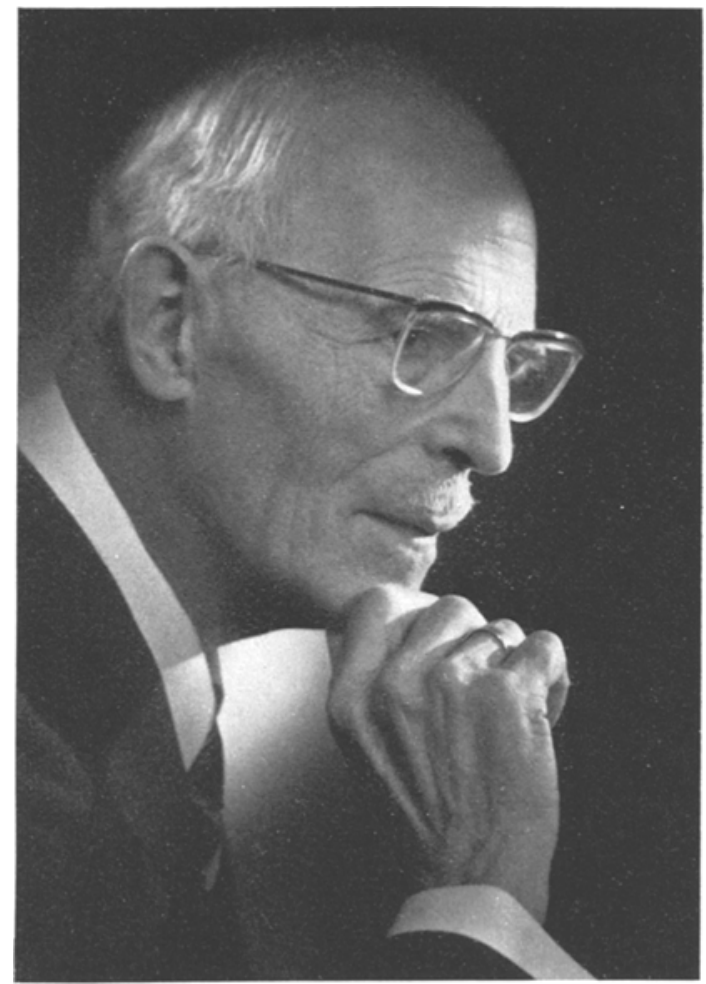

Foto: Dittmar-Renner, Bad Kissingen
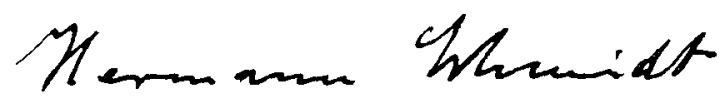

Die Geologische Vereinigung verlieh im Jahre 1974 die Gustav-Steinmann-Medaille

an

\title{
Professor Dr. Hermann Schmidt
}

dem hervorragenden Forscher und Lehrer der Geologie als historischer Wissenschaft in Würdigung seines Gesamtwerkes 